\title{
Genes involved in meso-diaminopimelate synthesis in Bacillus subtilis: identification of the gene encoding aspartokinase I
}

\author{
Claude-Alain H. Roten, Cyrille Brandt and Dimitri Karamata* \\ Institut de Génétique et Biologie Microbiennes, Rue César-Roux 19, 1005 Lausanne, Switzerland
}

(Received 8 October 1990; revised 4 December 1990; accepted 11 December 1990)

\begin{abstract}
Thermosensitive mutants of Bacillus subtilis deficient in peptidoglycan synthesis were screened for mutations in the meso-diaminopimelate ( $\mathrm{LD}-\mathrm{A}_{2} \mathrm{pm}$ ) metabolic pathway. Mutations in two out of five relevant linkage groups, $l s s B$ and $l s s D$, were shown to induce, at the restrictive temperature, a deficiency in $L D-A_{2} p m$ synthesis and accumulation of UDP-MurNAc-dipeptide. Group $l s s B$ is heterogeneous; it encompasses mutations that confer deficiency in the deacylation of $\mathrm{N}$-acetyl-LL- $\mathrm{A}_{2} \mathrm{pm}$ and accumulation of this precursor. Accordingly, these mutations are assigned to the previously identified locus dapE. Mutations in linkage group $l s s D$ entail a thermosensitive aspartokinase $I$. Therefore, they are most likely to affect the structural gene of this enzyme, which we propose to designate dapG. Mutation pyc-1476, previously reported to affect the pyruvate carboxylase, was shown to confer a deficiency in aspartokinase $\mathrm{I}$, not in the carboxylase, and to belong to the dapG locus. $\operatorname{dap} G$ is closely linked to spoVF, the putative gene of dipicolinate synthase. In conclusion, mutations affecting only two out of eight steps known to be involved in $\mathrm{LD}-\mathrm{A}_{2} \mathrm{pm}$ synthesis were uncovered in a large collection of thermosensitive mutants obtained by indirect selection. We propose that this surprisingly restricted distribution of the thermosensitive dap mutations isolated so far is due to the existence, in each step of the pathway, of isoenzymes encoded by separate genes. The biological role of different aspartokinases was investigated with mutants deficient in dapE and $\operatorname{dap} G$ genes. Growth characteristics of these mutants in the presence of various combinations of aspartate family amino acids allow a reassessment of a metabolic channel hypothesis, i.e. the proposed existence of multienzyme complexes, each specific for a given end product.
\end{abstract}

\section{Introduction}

Biosynthetic pathways of the aspartate family amino acids supply metabolites for two essential processes in bacteria: L-methionine, L-threonine, L-isoleucine and $\mathrm{L}$-lysine are required for protein synthesis, whereas mesodiaminopimelate ( $\mathrm{LD}-\mathrm{A}_{2} \mathrm{pm}$ ) is an essential constituent of peptidoglycan. In spore-forming bacilli, this metabolic pathway has an even more important role since it encompasses not only the synthesis of both $L D-\mathrm{A}_{2} \mathrm{pm}$ and dipicolinate, two essential constituents of the spore, but also that of antibiotics such as colistin in Bacillus colistinus (Ito et al., 1969) and $\beta$-lactam antibiotics

Abbreviations: LD-A 2 pm, meso-diaminopimelate; AKI, AKII and AKIII, aspartokinase I, II and III; MNNG, $N$-methyl- $N$ '-nitro- $N$ nitrosoguanidine; ND, nephelometric density; GlcNAc, $N$-acetylglucosamine; MurNAc, $N$-acetylmuramate.

Dedication: This contribution is dedicated to the late Howard J. Rogers. He will always be remembered for the enthusiasm and unfailing curiosity that kept him busy at the bench until surprised by death, and made him such a stimulating colleague.
(Higgens \& Kastner, 1971; Mendelovitz \& Aharonowitz, 1982). In Bacillus subtilis, genetic characterization of the LD-A $A_{2}$ pm pathway cannot be approached through isolation of auxotrophic mutants since available strains are not endowed with an active LD- $A_{2}$ pm uptake system. Therefore, mutants with deficient enzymes in this pathway were searched for among stable L-forms (Ward, 1975), or conditional lethal, thermosensitive mutants (Buxton, 1978; Buxton \& Ward, 1980). The latter approach resulted in the identification of only two classes of mutations; the first one was shown to affect dapE, a gene involved in deacylation of $N$-acetyl-LL- $\mathrm{A}_{2} \mathrm{pm}$, whereas the second one was mistakenly (see below) assigned to $p y c A$, the structural gene of pyruvate carboxylase. Mutants blocked in LD-A ${ }_{2} \mathrm{pm}$ synthesis offer a unique system to study in vivo the biological role of key enzymes involved in the pathway. Moreover, a somewhat different approach to the study of the biological role of aspartokinase I (AKI) was recently reported by Zhang \& Paulus (1990). They obtained a mutant, possessing an AKI apparently no longer subject 
to feedback inhibition by $\mathrm{LD}-\mathrm{A}_{2} \mathrm{pm}$, likely to be affected in the AKI gene.

Previously, a large collection of thermosensitive mutants of $B$. subtilis, obtained by indirect selection, had been screened for those lysing at the restrictive temperature. Five linkage groups were identified, $l s s A$ to $D$ and $l s s F$, which encompass genes involved in peptidoglycan synthesis (Brandt \& Karamata, 1987). When cultures of mutants affected in these genes are shifted to the nonpermissive temperature, they undergo after a short delay a more or less massive lysis. In the present work, mutations belonging to two of the five lss linkage groups are shown to specifically affect the synthesis of LD-A ${ }_{2}$ pm. $l s s B$ is involved in $N$-acetyl-LL- $\mathrm{A}_{2}$ pm deacylation, whereas $l s s D$ is probably the structural gene of aspartokinase I. The existence of a mutant deficient in AKI allowed us to examine the biological role of this enzyme.

\section{Methods}

Strains. The bacterial strains used are listed in Table 1.

Media and growth conditions. LA, SA, SATT, SAT2T, TS and S media were described by Karamata \& Gross (1970). MS was according to Sargent (1973), and sporulation medium according to Schaeffer et al. (1965). Solid media were supplemented with $1.5 \%(w / v)$ agar (Difco) or $1 \cdot 2 \%(\mathrm{w} / \mathrm{v})$ agar (Gibco). Unless otherwise stated, amino acids $\left(20 \mu \mathrm{g} \mathrm{ml}^{-1}\right)$ and bases $\left(50 \mu \mathrm{g} \mathrm{ml}^{-1}\right)$ were added when required.

Liquid cultures were aerated by bubbling, and the cell mass followed by nephelometric density (ND) measured on a Unigalvo (Corning EEL) nephelometer. For an exponentially growing culture in SA medium, a ND reading of 100 corresponds to $0.11 \mathrm{mg} \mathrm{ml}^{-1}$ dry weight (about $6 \times 10^{7}$ bacteria $\mathrm{ml}^{-1}$ ). Cultures were started by inoculating a freshly grown colony. They were incubated overnight at room temperature and further diluted while still in the exponential growth phase. For cultures in MS medium, overnight incubation was at $30^{\circ} \mathrm{C}$ and the medium supplemented with $0.001 \%$ casein hydrolysate (Sargent, 1973).

Transformation. Transformation procedures and media were as described by Karamata \& Gross (1970). Inheritance of the spoVFI marker was tested on prototrophic and thermoresistant recombinants purified by streaking on appropriately supplemented TS plates and incubation at $47^{\circ} \mathrm{C}$. The media for selection and purification of $\mathrm{Ts}^{+}$ recombinants contained all amino acids derived from L-aspartate (L-lysine, L-methionine, L-threonine and L-isoleucine), whose presence was shown to be necessary for a clear-cut expression of the thermosensitive phenotype by recipient dapG strains (Fig. $1 b$ and Discussion). Purified colonies were transferred on Schaeffer sporulation medium (Schaeffer et al., 1965) with or without dipicolinate $\left(100 \mu \mathrm{g} \mathrm{ml}^{-1}\right)$. After $48 \mathrm{~h}$ incubation at $30^{\circ} \mathrm{C}$, spores were replicated on LA plates and screened for thermosensitivity/resistance by $16-18 \mathrm{~h}$ incubation at $80^{\circ} \mathrm{C}$, followed by $24-36 \mathrm{~h}$ incubation at $30^{\circ} \mathrm{C}$.

Extraction and analysis of peptidoglycan nucleotide precursors. Cultures $(200 \mathrm{ml})$ in SATT medium supplemented with $\mathrm{N}$-acetylglucosamine (GIcNAc) $(75 \mu \mathrm{M})$ were maintained in the exponential growth phase at $30^{\circ} \mathrm{C}$ for at least five generations. They were shifted to $45^{\circ} \mathrm{C}$ at an ND between 70 and 100. To obtain a short transition period between permissive and restrictive temperature (about $1 \mathrm{~min}$ ), flasks containing the cultures were briefly dipped into a waterbath at $70{ }^{\circ} \mathrm{C}$ and then transferred to $45^{\circ} \mathrm{C}$. After $13 \mathrm{~min}$ further incubation, bacteria were harvested on a Whatman filter $(\mathrm{GF} / \mathrm{F}$, diameter $45 \mathrm{~mm})$, washed for less than $2 \mathrm{~min}$ with ice-cold water, and extracted from the filter into $10 \%(\mathrm{w} / \mathrm{v})$ trichloroacetic acid (TCA) at room temperature. After ether extraction of TCA, the aqueous extract was neutralized with $\mathrm{NaOH}$ and concentrated by evaporation under vacuum. $N$-Acetyl-D$\left[1^{-14} \mathrm{C}\right]$ glucosamine $\left(0.12 \mu \mathrm{Ci} \mathrm{m}^{-1} ; 4.44 \mathrm{kBq} \mathrm{ml}^{-1}\right)$ was added to the culture $12 \mathrm{~min}$ before the temperature shift. Under the growth conditions used here, labelling of the hexosamine-containing soluble precursors can be considered as similar to continuous labelling, since (i) the global intracellular amount of precursors is equivalent to the cell wall mass synthesized during about only $0 \cdot 1$ generation time (unpublished observations) and (ii) presence of $75 \mu \mathrm{M}-\mathrm{GlcN}$ Ac in the growth medium almost completely inhibits endogenous GlcNAc synthesis (Bates \& Pasternak, 1965). Indeed, our experiments (results not presented) show that the specific activity in extracted nucleotide pools amounts to at least $80 \%$ of that of $\left[{ }^{14} \mathrm{C}\right] \mathrm{GlcNAc}$ present in the medium.

The nucleotide precursors in the extracts were first partially purified on a Sephadex G25 column $(1.5 \times 90 \mathrm{~cm})$ (Mengin-Lecreulx et al., 1982). Elution with deionized water was at a flow rate of $0 \cdot 2$ $0.5 \mathrm{ml} \mathrm{min}^{-1}$. Hexosamine-containing nucleotides, excluded from the gel by a charge effect, were recovered immediately after the void volume in two peaks (a rather wide one followed by a small one), which were pooled and concentrated by evaporation under vacuum. These pools were adjusted to $10 \mathrm{mM}-\mathrm{HCl}(5 \mathrm{ml})$ and chromatographed according to Good \& Tipper (1972) on a Dowex-1 $\times 2$ (200-400 mesh) column $(0.6 \times 5.5 \mathrm{~cm})$, equilibrated with $10 \mathrm{~mm}-\mathrm{HCl}$. They were eluted with a $100 \mathrm{ml}$ linear gradient of $\mathrm{NaCl}(0-0.6 \mathrm{~m}$ in $10 \mathrm{~mm}-\mathrm{HCl})$ at a rate of $22 \mathrm{ml} \mathrm{h}^{-1}$. Nucleotide precursor peaks were detected by $\mathrm{UV}$ absorption and radioactivity. The identity of UDP was confirmed by its UV absorption spectrum. Fractions corresponding to each main peak were pooled and desalted on a Sephadex G25 column. UDPMurNAc-tripeptide was well separated in the first elution peak, which was followed by the UDP-MurNAc-pentapeptide peak, and by a rather wide peak containing UDP-GIcNAc, UDP-MurNAc and UDPMurNAc-L-alanine. UDP-MurNAc-dipeptide, the last precursor eluted, was poorly separated from the preceding one. These nucleotide preparations were hydrolysed in $4.16 \mathrm{M}-\mathrm{HCl}$ under vacuum in nitrogenflushed ampoules $\left(8 \mathrm{~h}\right.$ at $\left.105^{\circ} \mathrm{C}\right)$. Under these conditions, the peptide moiety of the precursors is fully hydrolysed without excessive degradation of hexosamines, allowing simultaneous estimation of amino acids and hexosamines on a Beckman Multichrome B amino acid analyser using ninhydrin detection. Hydrolysis of GlcNAc and MurNAc standards gave glucosamine and muramic acid yields of $90 \%$ and $87 \%$, respectively; these figures were used to correct values obtained for our samples.

Analysis of $\mathrm{LD}-\mathrm{A}_{2} \mathrm{pm}$ soluble precursor pools. Culture conditions, labelling by $\mathrm{L}-\left[{ }^{14} \mathrm{C}\right]$ aspartate, and precursor extraction (from one-litre cultures) were as described for preparation of the substrate for the $\mathrm{N}$-acetyl-LL-A 2 pm deacylase assay (see below). Precursor-containing solutions were lyophilized. Adequate samples in $\mathrm{H}_{2} \mathrm{O}$ were loaded on Whatman 3MM paper and chromatographed, according to Ruhland $e t$ al. (1955). The chromatograms were analysed by ninhydrin staining in acid conditions. The spots of LD-A $\mathrm{A}_{2} \mathrm{pm}, \mathrm{LL}-\mathrm{A}_{2} \mathrm{pm}$ and $N$-acetyl-LL$\mathrm{A}_{2}$ pm were identified on a chromatogram obtained with the standard compounds. For a quantitative estimation of the labelled compounds, the spots were cut out, eluted with $1 \mathrm{ml}$ water, and the radioactivity was measured by liquid scintillation. To ascertain the identity of the $N$ acetyl-LL-A $\mathrm{A}_{2} \mathrm{pm}$, the spot was cut out, eluted with water and hydrolysed $\left(6 \mathrm{M}-\mathrm{HCl}, 105^{\circ} \mathrm{C}, 2 \mathrm{~h}\right)$; the hydrolysis product was chromatographed again and identified as $\mathrm{LL}-\mathrm{A}_{2} \mathrm{pm}$. 
Table 1. Strains of B. subtilis 168 and $B$. licheniformis

\begin{tabular}{|c|c|c|}
\hline Strain & Genotype or phenotype & Source, reference or construction \\
\hline \multicolumn{3}{|l|}{ B. subtilis } \\
\hline 168 & $\operatorname{trp} C 2$ & \\
\hline $1 \mathrm{~S} 83$ & pheAl spoVFI trpC2 & $\begin{array}{l}\text { BGSC*; Balassa et al. (1979); spoVFl was formerly } \\
\text { designated dap-l (Piggot \& Hoch, 1985) }\end{array}$ \\
\hline BD96 & fur $A l$ & Dubnau et al. (1967) \\
\hline JH879 & pyrA 5 metC 3 pycA19 & Strain PB5033 of Gianni \& Galizzi (1986) $\dagger$ \\
\hline GSY403 & phe $A 3_{+}^{+} \operatorname{trpC2}$ & C. Anagnostopoulos, INRA, Jouy-en-Josas, France \\
\hline E10 & $\operatorname{trpC} 2$ thy Al thy $B 1$ gtaC $x t l-2$ & Karamata \& Gross (1970) \\
\hline L1440 & Prototroph & Mauël \& Karamata (1984) \\
\hline L5025 & pural6 leuA8 ilval lys-3I & Brandt \& Karamata (1987) \\
\hline L3890 & purA 16 metC 3 ilval & \\
\hline L2010 & $\operatorname{trpC} 2$ thy Al thyB 1 gtaC2 xtl-2 dapEIO & $\begin{array}{l}\text { Brandt } \& \text { Karamata }(1987) \\
\text { dapE } 10 \text { was previously designated } / s s B 10\end{array}$ \\
\hline L2012 & $\operatorname{trpC} 2$ thy AI thyBl gtaC2 xtl-2 lssB12 & Brandt \& Karamata (1987) \\
\hline L2023 & $\operatorname{trpC} 2$ thy $A 1$ thy $B 1$ gtaC2 $x t l-2$ dapE23 & $\begin{array}{l}\text { Brandt \& Karamata }(1987) \\
\text { dapE } 23 \text { was previously designated } / s s B 23\end{array}$ \\
\hline L2028 & $\operatorname{trpC2}$ thy Al thy $B$ l gtaC2 $x t l-2$ dapG28 & $\begin{array}{l}\text { Brandt \& Karamata ( } 1987) \\
\text { dapG } 28 \text { was previously designated } l s s D 28\end{array}$ \\
\hline L2031 & $\operatorname{trpC} 2$ thy Al thyBl gtaC2 xtl-2 lssB3l & Brandt \& Karamata (1987) \\
\hline L2100 & leuA8 illal lys-3l & Brandt \& Karamata (1987) \\
\hline L2123 & leuA8 ileAl lys-3I dapE23 & $\begin{array}{l}\text { Brandt \& Karamata ( } 1987) \\
\text { dapE23 was previously designated } 1 s s B 23\end{array}$ \\
\hline L2127 & leuAs ile Al lys-3l dapG27 & $\begin{array}{l}\text { Brandt \& Karamata (1987); } \\
\text { dapG27 was previously designated } \text { Iss D27 }\end{array}$ \\
\hline L2223 & leuA8 ill:Al dapE23 & $\mathrm{L} 3890 \rightarrow \mathrm{L} 2123 \S$ \\
\hline L2227 & leuA8 ilt:Al dapG 27 & $\mathrm{~L} 3890 \rightarrow \mathrm{L} 2127 \S$ \\
\hline L2128 & leuAs illal lys-3l dapG28 & L2028 $\rightarrow$ L5025\% \\
\hline L2328 & leuAs furAl dapG 28 & $\mathrm{BD} 96 \rightarrow \mathrm{L} 21289$ \\
\hline L2327 & phe $A 3$ ilt Al lys-3l dapG27 & GSY $403 \rightarrow$ L21279 \\
\hline MS320 & $\operatorname{trp} C 2$ thy Al thy Bl dapE320 & Buxton \& Ward (1980) \\
\hline RB1950 & purA16 metB5 ill Al dapG1476 & Buxton (1978); dapG I476 was previously designated $p y c$ \\
\hline \multirow{2}{*}{$\begin{array}{l}\text { B. licheniformis } \\
\text { NCTC } 6346\end{array}$} & & \\
\hline & $\mathrm{His}^{-}$ & Ward (1974) \\
\hline
\end{tabular}

* Bacillus Genetic Stock Center, Ohio. USA.

† Genotype pyr metC3 pycA of strain PB5033, constructed by J. Hoch, was reported by Gianni \& Galizzi (1986). Precise designation of the plc $A$ mutation is from $J$. Hoch (personal communication).

$¥ p h e A I$ and $p h e A 3$ are different mutations (C. Anagnostopoulos, personal communication), but both were called in the past phe Al. Aphe ${ }^{+}$(Mauël et al. 1989) corrects phe A3, but, according to the restriction map of Ferrari et al. (1982), it should not correct pheAl (P. Hauser, personal communication).

$\S$ Lys $^{+}$recombinant was obtained by transformation with non-saturating concentration of DNA. The arrow points from donor to recipient

9 Construction by congession with saturating concentrations of DNA. The arrow points from donor to recipient.

Apartokinase ( $A K ; E C 2,7.2 .4)$ assay. Cell extracts were obtained essentially according to Ward (1975). One-litre cultures were grown in MS medium supplemented with required amino acids $\left(40 \mu \mathrm{g} \mathrm{ml}^{-1}\right)$ and bases $\left(100 \mu \mathrm{g} \mathrm{ml}^{-1}\right)$, as well as with $0.001 \%$ casein hydrolysate. Even in the absence of any specific amino acid requirement, MS medium was supplemented with $20 \mu \mathrm{g} \mathrm{ml}^{-1}$ each of L-lysine, L-methionine, Lthreonine and $\mathrm{L}$-isoleucine. After at least two generations at $30^{\circ} \mathrm{C}$, cells were harvested by centrifugation and the pellet resuspended in $25 \mathrm{ml}$ $20 \mathrm{~mm}$-potassium phosphate, $\mathrm{pH} 7 \cdot 5$. Cells were recentrifuged, resuspended in $3 \mathrm{ml}$ of the same buffer and sonicated $16 \times 10 \mathrm{~s}$. The sonicate was mixed with $9 \mathrm{ml}$ of a solution of saturated ammonium sulphate and $0.1 \mathrm{~mm}$-EDTA at $\mathrm{pH} 7.7$. After $1 \mathrm{~h}$, the solution was centrifuged $(20 \mathrm{~min}$ at $39100 \mathrm{~g})$, the pellet resuspended in a solution $(50 \mathrm{~mm}$ diethanolamine. $\mathrm{HCl}, 1 \mathrm{mM}-\beta$-mercaptoethanol, $1 \mathrm{~mm}$-EDTA) at $\mathrm{pH} 8.5$ and dialysed for $4 \mathrm{~h}$ at $4{ }^{\circ} \mathrm{C}$ against the same solution. The extract was stored below $-20^{\circ} \mathrm{C}$ and its protein content determined by the Lowry method.

AK activity was measured according to Paulus \& Gray (1967). Formation of $\beta$-L-aspartyl phosphate, subsequently converted into $\beta$-L- aspartyl hydroxamate, was followed by colorimetry: $1 \mu \mathrm{mol}$ of $\beta$-Laspartyl phosphate $\mathrm{ml}^{-1}$ is equivalent to an $A_{520}$ of $0 \cdot 4$. The reaction mixture contained: $11.1 \mathrm{~mm}$-ATP, $11.1 \mathrm{~mm}$-creatine phosphate, $2.47 \mathrm{U} \mathrm{ml}^{-1}$ creatine kinase (EC 2.7.3.2), $11.1 \mathrm{mM}-\mathrm{MgCl}_{2}, 11.1 \mathrm{~mm}-\mathrm{L}-$ aspartate, and $0.88 \mathrm{~mm}-\mathrm{NH}_{2} \mathrm{OH} . \mathrm{KCl}, \mathrm{pH} 8$. The reaction was initiated by enzyme addition. For initial experiments, the total volume of the reaction mixture was $0.45 \mathrm{ml}$, with $0.5 \mathrm{mg}$ protein of the enzyme extract, and the reaction was stopped after $30 \mathrm{~min}$ by addition of $0.25 \mathrm{ml} 50 \%$ TCA and $0.1 \mathrm{ml} 2 \mathrm{M}-\mathrm{FeCl}_{3}$. For the following experiments, the volume of the reaction mixture was $0.21 \mathrm{ml}$ with $0.42 \mathrm{mg}$ protein of the enzyme extract, and the reaction was terminated by addition of TCA and $\mathrm{FeCl}_{3}$ as before. Background was measured on an incubation mixture where the substrate, L-aspartate, was added after TCA and $\mathrm{FeCl}_{3}$. The activity associated with $\mathrm{AKI}$ was obtained as the difference of activities measured with and without $2.22 \mathrm{mM}-\mathrm{LD}-\mathrm{A}_{2} \mathrm{pm}$, a specific inhibitor of AKI (Rosner \& Paulus, 1971; Zhang et al., 1990).

$N$-Acetyl-LL- $A_{2}$ pm deacylase (EC 3.5.1.47) assay. Cell extracts were obtained from cultures grown in SAT2T. After five generations at 
$30{ }^{\circ} \mathrm{C}$, cells were harvested by centrifugation at a ND of $90(0 \cdot 1 \mathrm{mg}$ dry weight $\mathrm{ml}^{-1}$ ). The pellet was resuspended in $4 \mathrm{ml}$ buffer ( $150 \mathrm{~mm}$-Tris, $0.75 \mathrm{mM}-\mathrm{MnCl}_{2}, 0.5 \mathrm{~mm}$-pyridoxal phosphate, $\mathrm{pH} 7.5$ ) and sonicated $24 \times 5 \mathrm{~s}$ with $25 \mathrm{~s}$ intervals between successive sonications. After removal of debris $\left(39100 \mathrm{~g}, 20 \mathrm{~min}\right.$, at $\left.4^{\circ} \mathrm{C}\right)$, the supernatant was immediately used as a crude extract. The protein content of the latter was determined by the biuret method (Layne, 1957).

The enzyme substrate was obtained from mutant MS320, which accumulates $N$-acetyl-LL-A 2 pm at $45^{\circ} \mathrm{C}$ (Buxton \& Ward, 1980), grown in five one-litre batches of appropriately supplemented MS medium. After incubation at $30^{\circ} \mathrm{C}$ to a ND of $80\left(0.085 \mathrm{mg}\right.$ dry weight $\left.\mathrm{ml}^{-1}\right)$, the culture was shifted to $45^{\circ} \mathrm{C}$, and $8 \mathrm{~min}$ after transfer $\mathrm{L}-\left[{ }^{14} \mathrm{C}\right]$ aspartate $(1$ $\left.\mathrm{nCi} \mathrm{m}^{-1}\right)$ was added to the culture, which was centrifuged 52 min later $(5 \mathrm{~min}$ at $13700 \mathrm{~g}$ ). Cells harvested by centrifugation were resuspended in $100 \mathrm{ml} \mathrm{H}_{2} 0$, heated for $5 \mathrm{~min}$ at $100^{\circ} \mathrm{C}$, and recentrifuged for $5 \mathrm{~min}$ at $4{ }^{\circ} \mathrm{C}$. The supernatant was kept and the pellet re-extracted in the same way. Pooled supernatants were partly purified according to Ward (1975), i.e. they were chromatographed on a Dowex $50\left(\mathrm{H}^{+}\right)$column $(1.5 \times 10 \mathrm{~cm})$ equilibrated with $0.01 \mathrm{M}-\mathrm{HCl}$. Elution $\left(60 \mathrm{ml} \mathrm{h}^{-1}\right)$ with a $400 \mathrm{ml}$ linear gradient of $\mathrm{HCl}(0 \cdot 01-2 \mathrm{M})$ yielded three radioactive peaks. Presence of $N$-acetyl-LL-A $\mathrm{A}_{2} \mathrm{pm}$ in the major peak $(71 \%$ of the radioactivity loaded on the column) was confirmed by paper chromatography after hydrolysis $\left(6 \mathrm{M}-\mathrm{HCl}, 2 \mathrm{~h}\right.$ at $\left.105^{\circ} \mathrm{C}\right)$ and removal of $\mathrm{HCl}$ under vacuum; the ninhydrin-staining and radioactivitycontaining spot was indistinguishable from that containing authentic LL-A 2 pm (Gilvarg, 1959). The specific activity of $N$-acetyl-LL-A $A_{2}$ pm was estimated by colorimetric assay of diaminopimelate after acid hydrolysis (Work, 1971).

$N$-acetyl-LL-A $\mathrm{A}_{2}$ pm deacylase was assayed by colorimetry (Sundharadas \& Gilvarg, 1967). The assay mixture $(32.5 \mu \mathrm{l})$, buffered by Tris $/ \mathrm{HCl}$ (28.5 mM, pH 7.5), contained $325 \mathrm{nmol} N$-acetyl-LL-A ${ }_{2} \mathrm{pm}$ and crude enzyme extract ( $200-300 \mu \mathrm{g}$ protein). After $20 \mathrm{~min}$ incubation at $37^{\circ} \mathrm{C}$, the reaction was stopped by addition of $17.5 \mu \mathrm{l}$ of $6 \mathrm{M}-\mathrm{HCl} ; 100 \mu \mathrm{l}$ ninhydrin $(5 \%, \mathrm{w} / \mathrm{v}$, in methyl cellosolve) was then added and the tube was incubated at $100^{\circ} \mathrm{C}$ for $5 \mathrm{~min}$. After cooling under running water, $1.1 \mathrm{ml}$ propanol was added and the $A_{420}$ recorded. Background was estimated on a mixture to which $\mathrm{HCl}$ was added before the enzyme extract. In these conditions, an $A_{420}$ increase of 0.005 corresponds to the conversion of $1 \mathrm{nmol} N$-acetyl-LL- $\mathrm{A}_{2} \mathrm{pm}$ into LL-A $\mathrm{A}_{2} \mathrm{pm}$.

Pyruvate carboxylase (EC 6.4.I.I) assay. Crude extracts, prepared like those for the AK assay (see above), were obtained from cells harvested in the late exponential growth phase (ND about 200). Pyruvate carboxylase activity was measured by transfer of radioactivity from labelled $\mathrm{CO}_{2}$ (Diesterhaft \& Freese, 1973). Labelled oxaloacetate, produced by pyruvate carboxylase, was converted into Laspartate through coupling with aspartate aminotransferase (Fisher \& Magasanik, 1984). The reaction medium contained: $25 \mathrm{~mm}$-Tris $\mathrm{pH} 7.5,10 \mathrm{~mm}-\mathrm{MgCl}_{2}, 5 \mathrm{~mm}-\mathrm{NaH}^{14} \mathrm{CO}_{3}\left(0 \cdot 1 \mu \mathrm{Ci} \mathrm{ml}^{-1} ; 3.7 \mathrm{kBq} \mathrm{ml}^{-1}\right)$, $5 \mathrm{~mm}$-sodium pyruvate, $0.12 \mathrm{~mm}$-acetyl-CoA, $5 \mathrm{~mm}$-ATP, $10 \mathrm{~mm}$ sodium glutamate, $20 \mathrm{~mm}$-pyridoxal phosphate, and $2 \mathrm{U} \mathrm{ml}^{-1}$ aspartate aminotransferase (EC 2.6.1.1). The reaction was initiated by addition of the enzyme extract and, 30 min later, stopped by addition of $2 \mathrm{M}-\mathrm{HCl}$ (half the volume of the reaction mixture). Samples $(100 \mu \mathrm{l})$ were dried for $3 \mathrm{~h}$ at $80^{\circ} \mathrm{C}$, resuspended in $1 \mathrm{ml} \mathrm{H}_{2} \mathrm{O}$ and their radioactivity measured by liquid scintillation counting. Volumes of the reaction mixtures were either 200 or $80 \mu \mathrm{l}$, with the addition of enzyme extracts containing 200 or $50 \mu \mathrm{g}$ protein, respectively.

Control experiments revealed that absence of acetyl-CoA totally abolished the observed enzyme activity, in agreement with Diesterhaft $\&$ Freese (1973). To confirm that pyruvate carboxylase activity was actually measured, we have shown that radioactivity incorporation was also totally abolished when the substrate, pyruvate, was omitted, or when the enzyme extract ( $50 \mu \mathrm{g}$ of protein) was incubated for $5 \mathrm{~min}$ with $16.7 \mu \mathrm{g}$ avidin just before the assay.

\section{Results}

\section{Preliminary screening of lss mutants}

To identify mutants deficient in LD-A ${ }_{2}$ pm synthesis, we screened our collection of thermosensitive lysis mutants, lss(Ts), deficient in peptidoglycan synthesis at the nonpermissive temperature. Shifting the latter strains from $30{ }^{\circ} \mathrm{C}$ to $45^{\circ} \mathrm{C}$ results in a limited nephelometric density increase followed, at around $20 \mathrm{~min}$, by a more or less massive lysis (Brandt \& Karamata, 1987). We exploited the well-known phenomenon that lysis induced by interference with peptidoglycan synthesis can be suppressed by simultaneous inhibition of protein synthesis (Buxton, 1978; Kirby \& Burnell, 1954; Meynell \& Meynell, 1970). It is generally accepted that mutants affected in the synthesis of LD-A $A_{2}$ pm are intrinsically also deficient in the formation of L-lysine or, depending on the exact site of the enzymic block (Fig. 2), of L-lysine and other amino acids belonging to the aspartate family. Therefore, the thermosensitive lysis phenotype of mutants deficient in LD-A ${ }_{2}$ pm synthesis should not be expressed unless the growth medium contains all amino acids whose synthesis has been affected by their dap mutations. Supplementation with LD- $\mathrm{A}_{2} \mathrm{pm}$ is ineffective

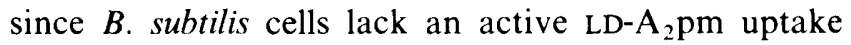
system (Ward, 1975; Buxton, 1978).

Cultures of $l y s^{+}$derivatives harbouring $l s s$ mutations, grown in minimal media with or without L-lysine, were shifted from $30^{\circ} \mathrm{C}$ to the non-permissive temperature, and their nephelometric density was followed. Only thermosensitive lysis strains belonging to linkage groups $l s s B$ and $l s s D$ were affected by the medium composition (Figs. $1 a, b$ ), revealing a deficiency in $\mathrm{LD}^{-\mathrm{A}_{2} \mathrm{pm}}$ synthesis. However, strains belonging to linkage group lss $B$ behaved differently from those belonging to group lss $D$ when the growth medium was supplemented with various combinations of aspartate family amino acids. Lysis of L2223 (lssB23) was abolished in absence of L-lysine (Fig. 1 $a$ ); supplementation with L-methionine and L-threonine as well as L-lysine did not influence the lysis kinetics observed in presence of L-lysine alone. Surprisingly, in the absence of L-lysine, growth of strain L2227 (lss D27) continued at $45^{\circ} \mathrm{C}$, but more slowly than that of the parent strain (Fig. 1b). Although supplementation of the medium with L-lysine stopped growth, the cultures did not show a clear lysis. The latter appeared only in medium supplemented with L-lysine as well as Lthreonine and L-methionine. These observations suggest that $l s s B$ and $l s s D$ loci concern enzymes located downand upstream from L-aspartate- $\beta$-semialdehyde, respectively (Fig. 2).

Absence of L-lysine almost completely abolished the lysis of mutant L2223 (lssB23) at $45^{\circ} \mathrm{C}$ (Fig. 1 a). This can 


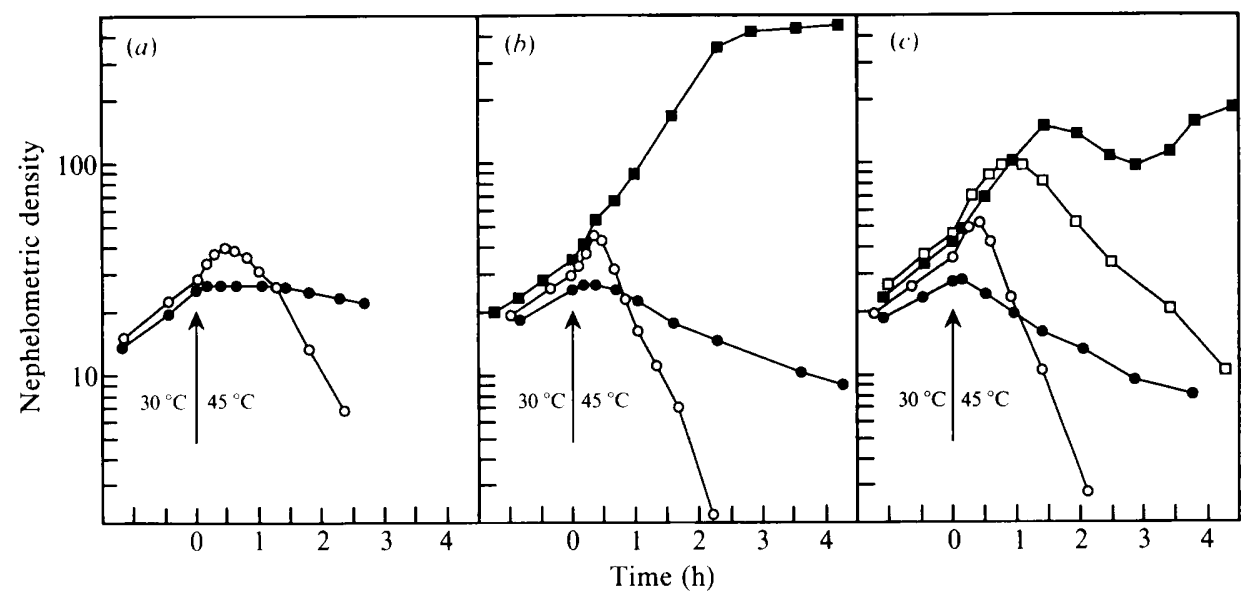

Fig. 1. Growth and lysis kinetics of mutants L2223 (lssB23) and L2227 (lssD27) at the non-permissive temperature in the presence of various combinations of aspartate family amino acids. Cultures, grown exponentially for four to five generations at $30^{\circ} \mathrm{C}$ in appropriately supplemented MS medium, were shifted to $45^{\circ} \mathrm{C}$ and the nephelometric density was followed. The time of shift is indicated by an arrow. Media were always supplemented by $40 \mu \mathrm{g} \mathrm{ml}^{-1}$ of L-leucine and L-isoleucine, which are required by all strains used. (a) Strain L2223 (lssB23) in MS medium with (O) or without (O) $20 \mu \mathrm{g} \mathrm{L-lysine} \mathrm{ml}^{-1}$. (b) Strain L2227 (lssD27) in MS medium without L-lysine $(\mathbb{\square})$, with $20 \mu \mathrm{g} \mathrm{L}$-lysine $\mathrm{ml}^{-1}(\mathbf{O})$, or with $20 \mu \mathrm{g} \mathrm{m} \mathrm{m}^{-1}$ each of L-lysine, L-methionine and L-threonine $(\mathrm{O})$. (c) strain L2227 (lssD27) in MS medium supplemented with $20 \mu \mathrm{g} \mathrm{L-lysine} \mathrm{ml}^{-1}$ with $(\mathrm{O})$ or without $(0) 20 \mu \mathrm{g} \mathrm{ml}^{-1}$ each of L-methionine and Lthreonine, and in MS medium supplemented with $20 \mu \mathrm{g} \mathrm{L}$-lysine $\mathrm{ml}^{-1}$ and $200 \mu \mathrm{g} \mathrm{ml}^{-1}$ of a mixture of D- and L-aspartate with ( $\square$ ) or without $(\boldsymbol{\square}) 20 \mu \mathrm{g} \mathrm{ml}^{-1}$ each of L-methionine and L-threonine.

Table 2. Pools of peptidoglycan nucleotide precursors in mutant and wild-type strains at non-permissive temperature

Labelled nucleotide precursors were extracted from cultures grown at $30^{\circ} \mathrm{C}$ and shifted to $45^{\circ} \mathrm{C}$, as described in Methods. Following a preliminary purification step on Sephadex G25, and chromatography on a small Dowex $-1 \times 2$ column, the nucleotide precursor content in major elution peaks was determined after analysis of amino acids and amino sugars. Minor peaks were quantified by their amount of radioactivity.

\begin{tabular}{|c|c|c|c|}
\hline \multirow[b]{2}{*}{ Precursor } & \multicolumn{3}{|c|}{$\begin{array}{c}\text { Amount of precursor } \\
{\left[\mathrm{nmol}(\mathrm{mg} \text { dry wt })^{-1}\right] \text { in strain }}\end{array}$} \\
\hline & $\mathrm{L} 2100\left(\mathrm{Ts}^{+}\right)$ & L2123 (lssB23) & L2127 (lssD27) \\
\hline \multirow{5}{*}{$\left.\begin{array}{l}\text { UDP-GlcNAc* } \\
\text { UDP-MurNAc } \\
\text { UDP-MurNAc-monopeptide }\end{array}\right\}$} & $0 \cdot 3$ & 0.1 & $0 \cdot 2$ \\
\hline & $0 \cdot 5$ & $3 \cdot 1$ & $1 \cdot 2$ \\
\hline & $1 \cdot 1$ & $6 \cdot 5$ & $5 \cdot 2$ \\
\hline & 0.1 & $<0 \cdot 1$ & $<0.1$ \\
\hline & $1 \cdot 1$ & $<0.1$ & $0 \cdot 2$ \\
\hline Total & $3 \cdot 0$ & $9 \cdot 8$ & 6.9 \\
\hline
\end{tabular}

* Includes UDP-GlcNAc and UDP-GlcNAc-enolpyruvate since both substances produce glucosamine upon acid hydrolysis.

be attributed to complete inhibition of protein synthesis due to L-lysine starvation, strongly suggesting that mutation lssB23 totally abolishes the activity of the enzyme affected. The latter statement correlates well with the absence of the UDP-MurNAc-pentapeptide pool (Table 2) and of peptidoglycan synthesis, at the nonpermissive temperature (Brandt \& Karamata, 1987, and not presented). However, absence of L-threonine and Lmethionine had a less drastic effect on the lysis kinetics of L2227 (lssD27); the decrease in nephelometric density was only slowed down (Fig. 1 b), but lysis did occur even in the presence of L-lysine only. This behaviour is likely to be due to a limited protein synthesis at $45^{\circ} \mathrm{C}$, and thus to some residual activity of the impaired function; this is in full agreement with both a reduced but significant UDP-MurNAc-pentapeptide pool (Table 2) and reduced peptidoglycan synthesis (Brandt \& Karamata, 1987, and not presented) at high temperature. 


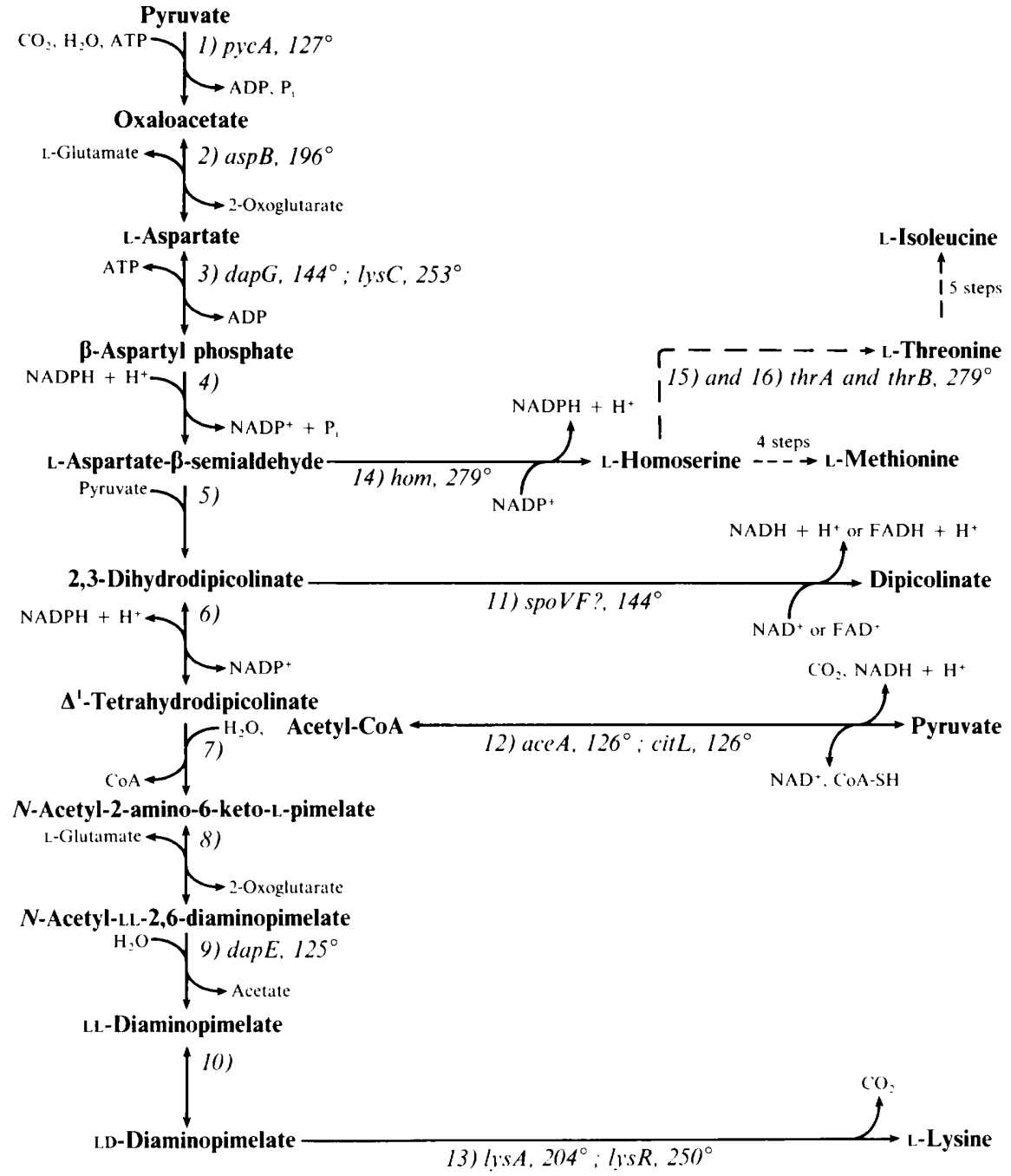

Fig. 2. Biosynthesis of the amino acids belonging to the L-aspartate family in B. subtilis (Ward, 1975). Enzymic activitıes are indicated as follows: 1, pyruvate carboxylase (EC 6.4.1.1); 2, aspartate aminotransferase (EC 2.6.1.1); 3, aspartokinases I, II and III (EC 2.7.2.4); 4, aspartate-semialdehyde dehydrogenase (EC 1.2.1.11); 5, dihydrodipicolinate synthase (EC 4.2.1.52); 6, dihydrodipicolinate reductase (EC 1.3.1.26); 7, tetrahydrodipicolinate acetyltransferase; 8 , acetyl-diaminopimelate aminotransferase; 9 , acetyldiaminopimelate deacylase (EC 3.5.1.47); 10, diaminopimelate epimerase (EC 5.1.1.7); 11, dipicolinate synthase; 12, the pyruvate dehydrogenase complex: 13, diaminopimelate decarboxylase (EC 4.1.1.20); 14; homoserine dehydrogenase (EC 1.1.1.3); 15, homoserine kinase (EC 2.7.1.39); 16, threonine synthase (EC 4 2.99.2). Genetic markers so far identified in $B$. subtilis are indicated in italic, and their positions on the chromosome are estimated in degrees essentially according to Zeigler (1990). lys $R$ is a new locus identified by mapping lysine auxotrophic mutations, which are associated with a deficiency in diaminopimelate decarboxylase activity (Shevtchenko et al., 1988). With the exception of reactions in L-threonine and L-methionine pathways, cosubstrates and coproducts of all enzymic steps are specified.

\section{Analysis of peptidoglycan and $L D-A_{2} p m$ soluble precursor pools}

Mutants deficient in LD- $\mathrm{A}_{2} \mathrm{pm}$ synthesis are affected in peptidoglycan formation since absence of $\mathrm{LD}^{-\mathrm{A}_{2} \mathrm{pm}}$ blocks peptidoglycan precursor synthesis at the level of UDP-MurNAc-dipeptide, which accumulates in the cytoplasm (Buxton \& Ward, 1980; Ward, 1975). Thus, to confirm our preliminary evidence that $l s s B$ and $l s s D$ loci are involved in LD- $\mathrm{A}_{2} \mathrm{pm}$ synthesis, we measured the nucleotide precursor pools of peptidoglycan in relevant strains at the non-permissive temperature, as described in Methods. Cells growing exponentially at $30^{\circ} \mathrm{C}$ were shifted to $45^{\circ} \mathrm{C}$; they were collected by filtration before the onset of lysis so as to minimize the loss of soluble metabolites. After TCA extraction and a partial purification step by gel filtration, the nucleotide precursors were fractionated on a Dowex- $1 \times 2$ ion-exchange resin. Finally, amino acid and amino sugar analyses of fractions corresponding to different peaks allowed 
Table 3. $\mathrm{N}$-Acetyl-LL-A $\mathrm{A}_{2} \mathrm{pm}$ deacylase activity in mutant and wild-type strains

Crude extracts were prepared from cultures growing exponentially in SAT2T medium at $30^{\circ} \mathrm{C}$. The reaction mixture contained 200-300 $\mu \mathrm{g}$ protein from crude extracts and was always incubated for $20 \mathrm{~min}$ at $37^{\circ} \mathrm{C}$. Conversion of $\mathrm{N}$-acetyl-LL-A $\mathrm{A}_{2} \mathrm{pm}$ into LL- $\mathrm{A}_{2} \mathrm{pm}$ was followed by colorimetry.

\begin{tabular}{lcc}
\hline \hline \multicolumn{1}{c}{ Strain } & $\begin{array}{c}\text { Enzyme activity } \\
\text { [nmol min }\end{array}$ (mg protein) $)^{-1}$ ] & $\begin{array}{c}\text { Percentage } \\
\text { relative } \\
\text { to L2100 }\end{array}$ \\
\hline L2100 & 1836 & 100 \\
MS320 (dapE320) & 31 & $1 \cdot 7$ \\
L2123 (lssB23) & 281 & $15 \cdot 3$ \\
L2127 (lssD27) & 1441 & $78 \cdot 5$ \\
\hline \hline
\end{tabular}

quantification of different precursors. As expected, mutations $l s s D 27$ and $l s s B 23$ conferred accumulation of considerable amounts of UDP-MurNAc-dipeptide and very low levels, or even absence, of UDP-MurNAcpentapeptide (Table 2), which is consistent with a defect in LD-A 2 pm synthesis. Furthermore, accumulation of CDP-glycerol, a soluble precursor of poly(glycerol phosphate), has also been observed in lssD27- and IsSB23-bearing strains at the non-permissive temperature (Pooley et al., 1991). However, since excretion of UDPlinked compounds has been reported (Szabo et al., 1989), the measured pools may well be underestimates of synthesized quantities of nucleotide precursors. Control experiments (not presented) revealed that peptidoglycan nucleotide precursor pools in strain L2100, the reference $\mathrm{Ts}^{+}$strain, were not significantly affected by the temperature shift.

In the experiment shown, the reference strain had a surprisingly high level of UDP-MurNAc-dipeptide, a level comparable to that of UDP-MurNAc-pentapeptide (Table 2). However, in other experiments performed on the same strain, UDP-MurNAc-pentapeptide was found to be the most abundant precursor specific for peptidoglycan synthesis (not presented). Comparable results were observed in Escherichia coli (Mengin-Lecreulx et al., 1982, 1983) and Staphylococcus aureus (Good \& Tipper, 1972).

For mutants belonging to group $l s s B$, we narrowed the range of enzymes to be assayed by examining their soluble $L D-A_{2} \mathrm{pm}$ precursor pools. Cultures growing exponentially in MS medium were shifted from $30^{\circ} \mathrm{C}$ to $45^{\circ} \mathrm{C}$, and $52 \mathrm{~min}$ later, hot-water cell extracts were prepared. Analysis of the extracts by paper chromatography revealed that group lss $B$ is heterogeneous. First, two mutations, lssB23 and $l s s B 10$, conferred accumulation of $N$-acetyl-LL-A ${ }_{2} \mathrm{pm}$; the observed pools were 17 and 11-fold higher, respectively, than that of the wildtype strain E10. This points to a deficiency in the $N$ -
acetyl-LL- $\mathrm{A}_{2} \mathrm{pm}$ deacylation, which is in excellent agreement with the very close genetic linkage between lssB23 and dapE320 (Brandt \& Karamata, 1987), a previously described mutation which is responsible for a deficiency of the $\mathrm{N}$-acetyl-LL- $\mathrm{A}_{2} \mathrm{pm}$ deacylase (Buxton \& Ward, 1980). Finally, mutants bearing the remaining mutations, $l s s B 12$ and $B 31$, did not accumulate any of the ninhydrin-staining $\mathrm{LD}-\mathrm{A}_{2} \mathrm{pm}$ precursors, in particular neither $N$-acetyl-LL- $\mathrm{A}_{2} \mathrm{pm}$ nor LL- $\mathrm{A}_{2} \mathrm{pm}$. Their chromatograms were characterized by an increased ninhydrin staining spot which may correspond to glutamate.

\section{Assay for activities of $A K$ and $N$-acetyl-LL- $A_{2} p m$ deacylase in cell extracts}

Our results suggest that group lss $B$ may comprise two loci, one of which being involved in the $N$-acetyl-LL$\mathrm{A}_{2} \mathrm{pm}$ deacylation, whereas the lss $D$ locus seems to be involved in the first stages of LD-A ${ }_{2} \mathrm{pm}$ synthesis.

Assays for $\mathrm{N}$-acetyl-LL-A $\mathrm{A}_{2} \mathrm{pm}$ deacylase activity (Sundharadas \& Gilvarg, 1967) were performed on crude extracts obtained from exponential-phase cultures grown at $30^{\circ} \mathrm{C}$ (Table 3 ). The very low level of deacylating activity in strain L2123 (lssB23), in full agreement with the analyses of precursor pools, establishes that mutation IssB23 confers a phenotype identical to that shown by the previously characterized mutation dapE320 (Buxton \& Ward, 1980). Accordingly $l s s B 10$ and $B 23$ were renamed dapE10 and E23. These assays have also revealed that IsSB12- and B3I-bearing mutants have wild-type levels of $N$-acetyl-LL-A ${ }_{2}$ pm deacylase (not presented). Incidentally, in our experiments, extracts of the wild-type strain (L2100) yielded specific deacylase activities four times higher than that measured by Buxton \& Ward (1980).

The requirement for L-lysine for full expression of the thermosensitive phenotype in mutant L2227 (IssD27) (Fig. $1 b$ ) suggests a deficiency of AKI activity. Indeed, AKII, the other major AK activity in $B$. subtilis 168 , is known to be both inhibited and repressed by lysine (Hampton et al., 1971; Graves \& Switzer, 1990; Zhang t al., 1990). Thus, presence of L-lysine in the growth medium would prevent AKII from substituting for the deficient AKI activity at the restrictive temperature. In addition, lss $D$, mapping at $144^{\circ}$ (Brandt \& Karamata, 1987 ), is located in a different region of the B. subtilis chromosome than aec $A$, the AKII locus, situated at $253^{\circ}$ (Petricek et al., 1989; Chen et al., 1989) and more recently renamed lysC (Lu et al., 1991). This prompted us to assay the activity of AKI. Cultures of strain L2227 (lssD27) and L2328 (lssD28), growing exponentially at $30{ }^{\circ} \mathrm{C}$ in MS medium, were harvested and $\mathrm{AK}$ activities were determined in ammonium sulphate precipitates of crude cell extracts (Table 4). When assayed at $37^{\circ} \mathrm{C}$, the activity of AKI was completely abolished in these 
Table 4. AK activities in cell extracts

Extracts were prepared from cultures growing exponentially at $30{ }^{\circ} \mathrm{C}$ in minimal medium supplemented with L-lysine, L-methionine, L-threonine and L-isoleucine. When required, bases were added at $100 \mu \mathrm{g} \mathrm{ml}^{-1}$. Aspartokinase activities were assayed on ammonium sulphate precipitates after suspension of the pellet and dialysis. Unless otherwise stated the reaction mixture $(0.21 \mathrm{ml})$ contained $0.42 \mathrm{mg}$ protein from the cell extract. Incubation time was always $30 \mathrm{~min}$.

\begin{tabular}{|c|c|c|c|}
\hline \multirow[b]{2}{*}{ Strain } & \multirow{2}{*}{$\begin{array}{l}\text { Assay } \\
\text { temp. } \\
\left({ }^{\circ} \mathrm{C}\right)\end{array}$} & \multicolumn{2}{|c|}{$\begin{array}{c}\text { Enzyme activity } \\
{\left[\mathrm{nmol} \min ^{-1}(\mathrm{mg} \text { protein })^{-1}\right]}\end{array}$} \\
\hline & & Total & AKI* \\
\hline $168+$ & $\begin{array}{l}25 \\
37\end{array}$ & $\begin{array}{r}9 \cdot 5 \\
10 \cdot 9\end{array}$ & $\begin{array}{l}5 \cdot 6 \\
3 \cdot 8\end{array}$ \\
\hline L1440 (wild-type) & $\begin{array}{l}25 \\
37\end{array}$ & $\begin{array}{l}2 \cdot 8 \\
4 \cdot 6\end{array}$ & $\begin{array}{l}2 \cdot 2 \\
2 \cdot 9\end{array}$ \\
\hline L2227 (lssD27) & $\begin{array}{l}25 \\
37\end{array}$ & $\begin{array}{l}2 \cdot 4 \\
2 \cdot 9\end{array}$ & $\begin{array}{l}0 \cdot 2 \\
0\end{array}$ \\
\hline L2227 (lssD27)† & $\begin{array}{l}25 \\
37\end{array}$ & $\begin{array}{l}2 \cdot 7 \\
0\end{array}$ & $\begin{array}{l}0.7 \\
0\end{array}$ \\
\hline L2328 (lssD28) & $\begin{array}{l}25 \\
37\end{array}$ & $\begin{array}{l}0 \cdot 6 \\
0\end{array}$ & $\begin{array}{l}0 \cdot 6 \\
0\end{array}$ \\
\hline $\mathrm{RB} 1950(p y c-1476)$ & $\begin{array}{l}25 \\
37\end{array}$ & $\begin{array}{l}0 \cdot 4 \\
0 \cdot 4\end{array}$ & $\begin{array}{l}0 \cdot 4 \\
0\end{array}$ \\
\hline $\begin{array}{l}\text { B. licheniformis } \\
\text { NCTC } 6346\left(\mathrm{His}^{-}\right)\end{array}$ & 30 & $10 \cdot 8$ & $5 \cdot 6$ \\
\hline
\end{tabular}

* Difference between activities obtained with and without LD-A $A_{2} \mathrm{pm}(2.2 \mathrm{mM})$ in the reaction mixture; addition of LD-A ${ }_{2} \mathrm{pm}$ inhibits AKI activity (Rosner \& Paulus, 1971).

$\dagger$ The reaction mixture $(0.45 \mathrm{ml})$ contained $0.5 \mathrm{mg}$ cell extract protein.

partially purified enzyme extracts. In vitro, even at $25^{\circ} \mathrm{C}$, the activity of this enzyme was very low, strongly suggesting that $l s s D$ is the structural gene of AKI. Thus, $l s s D$ was renamed $\operatorname{dap} G$, in line with the nomenclature used in E. coli (Cohen \& Saint-Girons, 1987). At $25^{\circ} \mathrm{C}$, total AK activities in extracts of strains L2227, L2328, and in particular RB1950 (see below), were very low. This apparently surprising observation is easily accounted for by (i) a very low level of AKI in vitro (see above), and (ii) a nearly complete repression of AKII and AKIII in the media used in our experiments (see Discussion). Finally, a control experiment performed on Bacillus licheniformis NCTC 6346 also revealed an LD- $\mathrm{A}_{2} \mathrm{pm}$ sensitive AK activity in this bacterium.

\section{Reassessment of the enzymic activity affected by the pyc-1476 mutation}

Although mutation pyc-1476 was reported to affect pyruvate carboxylase activity (Buxton, 1978), the phenotype of strain RB1950 (pyc-1476) was almost indistinguishable from that of strain L2227 (dapG27). Indeed, (i) both strains have a lysine-dependent temperature- sensitive lysis phenotype, (ii) they accumulate UDPMurNAc-dipeptide, suggesting a defect in LD-A 2 pm synthesis, and (iii) their thermosensitive phenotype is partially corrected by including aspartate in the growth medium (Buxton, 1978; Fig. 1c). These observations, coupled to that of very close linkage between pyc-1476 and dapG27 (Brandt \& Karamata, 1987), suggested the need for a reassessment of enzymic activities in strain RB1950. Assays performed with crude extracts of strain RB1950 (Table 4) revealed a deficiency in AKI activity, confirming that pyc-1476 and dapG27 affect the same gene. Thus, we propose to designate the former marker dapG1476.

Pyruvate carboxylase activity in extracts of strain RB1950 exhibits the same temperature-dependent profile as the wild-type strain L1440, and thus shows no sign of thermosensitivity. The apparently reduced level of pyruvate carboxylase activity in strain RB1950 (40\% of that of the wild-type) may well be due to repression by Laspartate present in the growth medium, a repression also observed with the wild-type strain. In addition, the observation that enzyme activity in mutants RB1950 and L2227 is approximately half that of the wild-type in the same growth media, could result from an increased Laspartate pool due to a poorly functioning mutated enzymic activity even at the permissive temperature (Buxton, 1978, and results not shown). Although we cannot account for the apparent pyruvate carboxylase deficiency in strain RB1950 reported by Buxton (1978), it is noteworthy that the assays described were performed in the absence of acetyl-CoA which, according to Diesterhaft \& Freese (1973) and to our observations (see Methods), is essential for pyruvate carboxylase activity in $B$. subtilis.

The reassignment of $p y c-1476$ resolves an ambiguity in the localization of the $p y c A$ locus and clarifies the mapping in the pyr region (Buxton, 1978; Piggot \& Hoch, 1985; Piggot, 1989; Zeigler, 1990). Indeed, mutation dapG1476 (previously designated pyc-1476), located at $144^{\circ}$ on the B. subtilis chromosome (Buxton, 1978; Brandt \& Karamata, 1987), is not related to mutation pyc $A 19$ (originally designated $a s p A$ ), which does confer a deficiency in pyruvate carboxylase activity (Hoch \& Mathews, 1972; Diesterhaft \& Freese, 1973), and behaves like an aspartate requiring auxotroph at all temperatures. In addition, three-point PBS1 transduction crosses (results not presented) confirm the order met $C, p y c A$, pyr $A$ and place $p y c A$ at $127^{\circ}$, in agreement with Piggot \& Hoch (1985) as well as with Mueller \& Taber (1989).

\section{Genetic linkage between dapG and spoVF}

Inspection of the genetic map of $B$. subtilis suggests that the dapG locus maps in the same region as $d p a-1$, a 
Table 5. Linkage of spoVF and dapG markers

Competent cells of strains L2327 (dapG27) and RB1950 (dapG1476) were transformed with indicated concentrations of donor DNA. Double recombinants, prototrophic and $\mathrm{Ts}^{+}$, obtained by pseudo-linkage, were either directly selected, or identified by screening of selected prototrophs. Cotransfer of the spoVF marker was determined as described in Methods.

\begin{tabular}{|c|c|c|c|c|c|c|}
\hline Donor & $\begin{array}{c}\text { DNA } \\
\text { concn } \\
\left(\mathrm{ng} \mathrm{m}^{-1}\right)\end{array}$ & Recipient & Selected marker(s) & $\begin{array}{l}\text { No. of } \\
\text { recombinants } \\
\text { tested }\end{array}$ & $\begin{array}{l}\text { Unselected } \\
\text { marker }\end{array}$ & $\begin{array}{l}\text { Percentage } \\
\text { of } \\
\text { co-transfer }\end{array}$ \\
\hline $\begin{array}{l}\text { IS83 (spoVFI pheAl) } \\
\lambda p h e^{+}\end{array}$ & $\begin{array}{r}300 \\
25\end{array}$ & L2327 (dapG27 pheA3 leuA8) & $p h e^{+} d a p^{+*}$ & 147 & $\begin{array}{l}\mathrm{Spo}^{-} \\
\mathrm{Leu}^{+}\end{array}$ & $\begin{array}{l}66 \\
9 \cdot 5\end{array}$ \\
\hline $\begin{array}{l}\text { GSY403 (phe A3) } \\
\lambda p h e^{+}\end{array}$ & $\begin{array}{l}300 \\
100\end{array}$ & L2327 (dapG27 pheA3 leuA8) & $p h e^{+}$dap ${ }^{+*}$ & 150 & $\begin{array}{l}\mathrm{Spo}^{-} \\
\mathrm{Leu}^{+}\end{array}$ & $\begin{array}{l}0 \\
4 \cdot 7\end{array}$ \\
\hline 1S83 (spoVF1 pur $\left.{ }^{+}\right)$ & 300 & RB1950 (dapG1476 purA16 metB5) & $\begin{array}{l}\text { pur }{ }^{+} \text {dap }^{+\dagger} \\
\text { pur }\end{array}$ & $\begin{array}{r}30 \\
300\end{array}$ & $\begin{array}{l}\mathrm{Spo}^{-} \\
\mathrm{Met}^{+}\end{array}$ & $\begin{array}{l}50 \\
5 \cdot 3\end{array}$ \\
\hline L1440 & 300 & RB1950 (dapG1476 purA16 metB5) & $\begin{array}{l}\text { pur }{ }^{+} \text {dap }^{+\dagger} \\
\text { pur }\end{array}$ & $\begin{array}{r}24 \\
300\end{array}$ & $\begin{array}{l}\mathrm{Spo}^{-} \\
\mathrm{Met}^{+}\end{array}$ & $\begin{array}{l}0 \\
9 \cdot 7\end{array}$ \\
\hline
\end{tabular}

* Direct selection for inheritance of both markers at $47^{\circ} \mathrm{C}$.

† Among the selected pur recombinants the inheritance of the $\mathrm{Ts}^{+}$phenotype was assessed by streaking on the appropriate minimal medium and incubation at $47^{\circ} \mathrm{C}$ (see Methods).

marker which probably belongs to spoVF (Piggot \& Hoch, 1985) and leads to generation of thermosensitive spores. As this phenotype is reverted by supplementation of the sporulation medium with dipicolinate, it seems likely that $d p a-I$ affects dipicolinate synthase (Balassa $e t$ al., 1979). Since, in addition, AKI and dipicolinate synthase belong to the same metabolic pathway, we assessed the linkage of the above markers by transformation.

Competent cells of L2327 (dapG27) and RB1950 (dapG1476) were transformed with saturating concentrations of donor DNA from strain 1S83 (spoVFl or dpa-1), as well as from a reference $s p o^{+}$strain (Table 5). To circumvent the high background of spontaneous thermoresistant revertants, double recombinants, prototrophic and thermoresistant, were selected. When strain L2327 (dapG27) was the recipient, double recombinants $\left(\mathrm{Phe}^{+}\right.$and $\left.\mathrm{Ts}^{+}\right)$were selected directly. With strain RB1950 (dapG1476), selected Pur ${ }^{+}$transformants were subsequently screened for thermoresistance. Double recombinants from both crosses were finally tested for the inheritance, by co-transfer, of the spoVF 1 marker. Both dapG27 and dapG1476 were about $60 \%$ cotransferred with spoVFl (Table 5), revealing a close linkage which is compatible with the possibility of coordinate transcription during sporulation.

\section{Discussion}

In this study, we have identified mutations which affect LD- $A_{2} \mathrm{pm}$ synthesis by screening thermosensitive mutants that lyse in non-permissive conditions due to deficiencies in peptidoglycan synthesis (Brandt \&
Karamata, 1987). Among five linkage groups harbouring such mutations, two, $l s s B$ and $l s s D$, were found to be involved in LD- $\mathrm{A}_{2} \mathrm{pm}$ synthesis.

Linkage group lss $B$, mapping at $125^{\circ}$, is heterogeneous. Mutations $l s s B 10$ and $B 23$ confer a deficiency in $N$ acetyl-LL- $\mathrm{A}_{2} \mathrm{pm}$ deacylation like the previously identified dapE320 mutation (Buxton \& Ward, 1980), to which they are very closely linked (Brandt $\&$ Karamata, 1987). Thus, mutations $l s s B 10$ and $B 23$ certainly affect the same gene as dapE320. Accordingly, they were renamed dapE10 and E23, respectively. However, we believe it premature to ascribe a precise function to the identified dap $E$ locus, since a mutation in the dapE gene of $E$. coli was shown to be complemented by a clone of $B$. subtilis DNA mapping at about $204^{\circ}$ (Shevtchenko et al., 1984; Aleksieva et al., 1985). The remaining group $l s s B$ mutations, $l s s B 12$ and $B 31$, do not confer a clear-cut phenotype; cell mass increase at $45^{\circ} \mathrm{C}$ is significant and the lysis, when observed, is very limited. Since, in addition, activities of the $N$-acetyl-LL- $\mathrm{A}_{2} \mathrm{pm}$ deacylase are normal, the function affected by these two mutations remains unclear.

Mutations in group lss $D$ were shown to affect AKI activity. They are most probably located in the structural gene of this enzyme which, according to the nomenclature used in E. coli, was denoted dapG. This locus was mapped at $144^{\circ}$ (Brandt \& Karamata, 1987) and shown to encompass a previously identified mutation, pyc-1476 (renamed dapG1476), which had been mistakenly assigned to the $p y c A$ locus (Buxton, 1978). Transformation crosses have revealed close linkage between $\operatorname{dap} G$ and spoVF, the putative structural gene of dipicolinate synthase. Since products of dapG27 and $d p a-1$ are part of the same metabolic pathway (Fig. 2), this linkage may 
suggest a coordinate gene expression. Indeed, AKI is expressed not only during vegetative growth, but also during sporulation (Hampton et al., 1971; Graves \& Switzer, 1990), where it is required for the synthesis of both $\mathrm{LD}-\mathrm{A}_{2} \mathrm{pm}$ and dipicolinate, two essential components of the spore. Activities of AKII and AKIII are, in contrast, hardly detectable during sporulation, where amino acids required for protein synthesis are derived from protein turnover (Hampton et al., 1971; Graves \& Switzer, 1990).

In conclusion, we found that a very large collection of thermosensitive mutants, obtained by indirect selection (Brandt \& Karamata, 1987), comprises only two classes of LD- $\mathrm{A}_{2} \mathrm{pm}$-deficient strains endowed with a rapid lysis phenotype, i.e. those deficient in gene $\operatorname{dap} G$ and those deficient in gene dapE. Interestingly, all previously isolated thermosensitive mutants (Buxton, 1978; Buxton \& Ward, 1980) affected in LD-A 2 pm synthesis were shown to owe their phenotype to deficiencies in the same $d a p G$ and $\operatorname{dapE}$ genes. These surprising observations suggest that mutations affecting nearly all of the genes involved in the eight enzymic steps required for LD$\mathrm{A}_{2} \mathrm{pm}$ synthesis have a very low probability of inducing a thermosensitive phenotype. Explanations based on intrinsic properties of the proteins (Karamata \& Gross, 1970) cannot be ruled out. However, it is possible that mutations in structural genes of most of the enzymes involved $\mathrm{LD}-\mathrm{A}_{2} \mathrm{pm}$ synthesis are complemented by products of genes encoding isoenzymes. Thus, to abolish such an enzymic activity, two specific mutations affecting both genetic determinants which encode the isoenzymes would be required. Considering that one of the two mutations would have to result in thermosensitivity, their simultaneous occurrence is even more unlikely.

Availability of a mutant with a thermosensitive AKI offers the possibility to study in vivo the regulation of $A K$ activities in $B$. subtilis. The three so far identified isoenzymes, AKI, II and III, participate in the first step of the biosynthesis of amino acids belonging to the aspartate family (Fig. 2). Their regulation has been studied in vitro. AKI appears to be rather specifically involved in the synthesis of LD- $A_{2} \mathrm{pm}$, by which it is inhibited (Rosner \& Paulus, 1971); its activity is largely independent of the amino acid composition of the growth medium (Rosner \& Paulus, 1971; Graves \& Switzer, 1990; Zang et al., 1990). AKII is both inhibited and repressed by lysine, and induced by methionine (Graves \& Switzer, 1990; Zhang et al., 1990). Analysis of the sequence of its structural gene has revealed the participation of L-lysine in the mechanism of expression of that gene (Chen et al., 1987; Chen \& Paulus, 1988). AKIII is induced by L-lysine, and repressed by Lthreonine as well as by several amino acids; in addition, it is inhibited by the simultaneous presence of Lthreonine and L-lysine (Graves \& Switzer, 1990). These observations clearly imply that AKII and AKIII are essentially devoted to protein synthesis. The former appears to be more specifically responsible for the synthesis of L-lysine and the latter for that of Lhomoserine or, more specifically, of L-threonine. They may well, to some extent, be interchangeable; for instance, in strain 168, AKII activity is more important than that of AKIII whereas the converse is found in the parent Marburg strain (Zhang et al., 1990).

Information on the biological role of AKs obtained from physiological studies of a dap $G$-bearing mutant can be summarized as follows. In minimal medium devoid of lysine, strain L2227 (dapG27) sustains substantial growth at the non-permissive temperature (Fig. 1b); apparently, AKII and AKIII substitute for the defective AKI. However, despite their overwhelming predominance over AKI in this medium (Hampton et al., 1971; Graves \& Switzer, 1990; Zhang et al., 1990), AKII and AKIII are unable to fully compensate the lack of AKI activity. Indeed, with the exception of a short period following the shift to non-permissive temperature, growth of L2227 (dapG27) is significantly impaired when compared to that of the parent strain at $45^{\circ} \mathrm{C}$ (Fig. 1). Thus, it would appear that either the level, a very high one, of AKII and AK III is still insufficient to fully compensate for absence of $\mathrm{AKI}$ or, for a more fundamental reason, the former enzymes are not easily interchangeable with the latter. Formation of very small colonies on minimal medium devoid of lysine, at $45^{\circ} \mathrm{C}$ (not presented), provides further evidence of a very incomplete substitution of AKII and AKIII for the deficient AKI.

In the presence of lysine, shift of L2227 (dapG27) to the non-permissive temperature is accompanied by an abrupt halt of mass increase (Fig. $1 b$ ). This observation is easily accounted for by inactivation of AKI, absence of the lysine-sensitive AKII activity, and a very low level of AKIII in strain 168 (Graves \& Switzer, 1990; Zhang et al., 1990). Nevertheless, the residual aspartokinase activity at $45^{\circ} \mathrm{C}$, presumably that of AKIII, may sustain a limited protein synthesis as suggested by a limited and slow lysis of the culture (see Fig. $1 b$ and Results). Thus, it would appear that collapse of AKI activity at the nonpermissive temperature blocks peptidoglycan and protein synthesis simultaneously, strongly suggesting that at the permissive temperature these syntheses were both relying on AKI activity. In any case, a rapid lysis is observed at $45^{\circ} \mathrm{C}$ only when all relevant amino acids are present in the medium allowing normal protein synthesis (Fig. 1b).

Finally, the inclusion of a high concentration of Laspartate in lysine-supplemented media restores substantial growth of strain L2227 (dapG27) at $45^{\circ} \mathrm{C}$ (Fig. 1 c), 
strongly suggesting that $\mathrm{AK}$ activity can be enhanced by an increased concentration of its substrate (Fig. 1c); it is not clear whether L-aspartate stimulates the activity of the thermolabile AKI or of AKIII or of both enzymes.

In summary, our in vivo observations are in excellent agreement with in vitro studies of the regulation of $\mathrm{AK}$ activities. They underline the important role of L-lysine in the regulation of AK activity in B. subtilis 168 , and they fully agree with the reported constant level of AKI activity, which is independent of the growth medium composition.

Recent experiments on AKII and AKIII mutants were analysed with respect to the metabolic channel hypothesis, according to which various aspartate family amino acids, including LD-A $A_{2} \mathrm{pm}$, would each be synthesized in separate compartments (Zhang et al., 1990; Zhang \& Paulus, 1990). Our observations, suggesting a certain degree of interchangeability between AKI and the other $\mathrm{AKs}$, would at first sight argue against independent metabolic channels. However, we would like to stress that substitution of AKI by AKII and AKIII is incomplete even in minimal medium where the latter enzymes are present at a high level. Therefore, in vivo studies of the AKI-deficient mutant could also be interpreted in favour of separate, but partially leaky, metabolic compartments. Indeed, if the concept of a channel were interpreted in terms of a multienzyme complex producing a specific end product, one could assume that each specific aspartokinase would bind preferentially to a given complex. For example, the LD-A ${ }_{2} \mathrm{pm}$ channel would have the highest affinity for AKI. However, each AK isoenzyme could also bind, albeit with somewhat lower affinities, to the other complexes, assuring some of their metabolic function. This model, involving multienzyme complexes, together with partial reciprocal substitution of isoenzymes, could readily account for the apparent partially communicating precursor pools.

We would like to thank the Nestlé Company, and Dr Rolf Jost, for precious help with amino acid analysis. The able technical assistance of Sophie Richard during genetical analyses is gratefully aknowledged.

\section{References}

Aleksieva, Z. M ., Shevtchenko, T. N. \& Malyuta, S. S. (1985). A study of lysine operon organization in Bacillus subtilis. Biopolimery $i$ Kletka 1, 156-158.

Balassa, G., Milhaud, P., Raulet, E., Silva, M. T. \& Sousa, J. C. F. (1979). A Bacillus subtilis mutant requiring dipicolinic acid for the development of heat-resistant spores. Journal of General Microbiology 110, 365-379.

BATES, C. J. \& PASTERnaK, C. A. (1965). The incorporation of labelled amino sugars by Bacillus subtilis. Biochemical Journal 96, 155-158.

BrandT, C. \& Karamata, D. (1987). Thermosensitive Bacillus subtilis mutants which lyse at the non-permissive temperature. Journal of General Microbiology 133, 1159-1170.
BUXTON, R. S. (1978). A heat-sensitive lysis mutant of Bacillus subtilis 168 with a low activity of pyruvate carboxylase. Journal of General Microbiology 105, 175-185.

BUXTON, R. S. \& WARD, J. B. (1980). Heat-sensitive lysis mutants of Bacillus subtilis 168 blocked at the three different stages of peptidoglycan synthesis. Journal of General Microbiology 120. 283-293.

Chen, N.-Y. \& Paulus, H. (1988). Mechanism of expression of the overlapping genes of Bacillus subtilis aspartokinase II. Journal of Biological Chemistry 263, 9526-9532.

Chen, N.-Y., Hu, F.-M. \& Paulus, H. (1987). Nucleotide sequence of the overlapping genes for the subunits of Bacillus subtilis aspartokinase II and their control regions. Journal of Biological Chemistry $\mathbf{2 6 2}$, 8787-8798.

Chen, N.-Y.. Zhang, J.-J. \& Paulus, H. (1989). Chromosomal location of the Bacillus subtilis aspartokinase II gene and nucleotide sequence of the adjacent genes homologous to uvrC and trx of Escherichia coli. Journal of General Microbiology 135, 2931-2940.

Cohen, G. N. \& Saint-Girons, I. (1987). Biosynthesis of threonine, lysine and methionine. In Escherichia coli and Salmonella typhimurium, Cellular and Molecular Biology, vol. 1, pp. 429-444. Edited by F.C. Neidhardt. Washington, DC: American Society for Microbiology.

Diesterhaft, M. D. \& FreEse, E. (1973). Role of pyruvate carboxylase, phosphoenolpyruvate carboxykinase, and malic enzymes during growth and sporulation of Bacillus subtilis. Journal of Biological Chemistry 248, 6062-6070.

Dubnau, D., Goldthwaite, C., Smith, I. \& Marmur, J. (1967). Genetic mapping in Bacillus subtilis. Journal of Molecular Biolog. 27, 163-185.

Ferrari, F. A., Land, D., Ferrari, E. \& Hoch, J. A. (1982) Molecular cloning of the $\operatorname{spoOB}$ sporulation locus in bacteriophage lambda. Journal of Bacteriology 152, 809-814.

Fisher, S. H. \& MAGaSanik, B. (1984). Synthesis of oxaloacetate in Bacillus subtilis mutants lacking the 2-ketoglutarate dehydrogenase enzymatic complex. Journal of Bacteriology 158, 55-62.

GianNI, M. \& GalizzI, A. (1986). Isolation of genes preferentially expressed during Bacillus subtilis spore outgrowth. Journal of Bacteriology 165, 123-132.

GiLvarG, C. (1959). $N$-succinyl-L-diaminopimelic acid. Journal of Biological Chemistry 234, 2955-2959.

Good, C. M. \& Tipper, D. J. (1972). Conditional mutants of Staphylococcus aureus defective in cell wall precursor synthesis. Journal of Bacteriology 111, 231-241

Graves, L. M. \& Switzer, R. L. (1990). Aspartokinase III, a new isozyme in Bacillus subtilis 168. Journal of Bacteriology 172, 218-223.

hampton, M. L., McCormick, N. C., Behforouz, N. C. \& Freese, E (1971). Regulation of two aspartokinases in Bacillus subtilis. Journal of Bacteriology 108, 1129-1134.

Higgens, C. E. \& Kastner, R. E. (1971). Streptomyces clavuligerus sp. nov., a $\beta$-lactam antibiotic producer. International Journal of Systematic Bacteriology 21, 326--331.

HOCH, J. A., \& Mathews, J. (1972). Genetic studies in Bacillus subtilis. In Spores V, pp. 113-116. Edited by H. O. Halvorson, R. Hanson \& L. L. Campbell. Washington, DC: American Society for Microbiology.

Ito, M., Aida, K. \& Uemura, T. (1969). Studies on the bacterial formation of a peptide antibiotic, colistin. Part III. On the biosynthetic pathway of $\alpha, \gamma$-diaminobutyric acid and relationship between colistin formation and amino acids metabolism in Bacillus colistinus Koyama. Agricultural and Biological Chemistry 33, 949-958.

Karamata, D. \& Gross, J. D. (1970). Isolation and genetic analysis of temperature-sensitive mutants of Bacillus subtilis defective in DNA synthesis. Molecular and General Genetics 108, 277-287.

KirbY, W. M. M. \& Burnell, J. M. (1954). Effect of combinations of antibiotics on lysis of Staphylococcus aureus by penicillin. Journal of Bacteriology 67, 50-52.

LAYNE, E. (1957). Spectrophotometric and turbidimetric methods for measuring proteins. Methods in Enzymology 3, 447-454.

LU, Y., CHEN, N.-Y. \& Paulus, H. (1991). Identification of aecA mutations in Bacillus subtilis as nucleotide substitutions in the 
untranslated leader region of the aspartokinase II operon. Journal of General Microbiology 137, (in the Press).

MauËL, C. \& Karamata, D. (1984). Characterization of proteins induced by mitomycin $C$ treatment of Bacillus subtilis. Journal of Virology 49, 806-812.

Mauël, C., Young, M., Margot, P. \& Karamata, D. (1989). The essential nature of teichoic acids in Bacillus subtilis as revealed by insertional mutagenesis. Molecular and General Genetics 215, 388-394.

Mendelovitz, S. \& Aharonowitz, Y. (1982). Regulation of cephamycin $\mathrm{C}$ synthesis, aspartokinase, dihydrodipicolinic acid synthetase, and homoserine dehydrogenase by aspartic acid family amino acids in Streptomyces clavuligerus. Antimicrobial Agents and Chemotherapy 21, 74-84.

Mengin-LecreulX, D., Flouret, B. \& Van Heijenoort, J. (1982). Cytoplasmic steps of peptidoglycan synthesis in Escherichia coli. Journal of Bacteriology 151, 1109-1117.

Mengin-LecreulX, D., Flouret, B. \& Van Heijenoort, J. (1983). Pool levels of UDP- $N$-acetylglucosamine and UDP- $N$-acetylglucosamine-enolpyruvate in Escherichia coli and correlation with peptidoglycan synthesis. Journal of Bacteriology 154, 1284-1290.

Meynell, G. G. \& Meynell, E. (1970). Genetic technique. In Theory and Practice in Experimental Bacteriology, pp. 256-294. Cambridge: Cambridge University Press.

MUELLER, J. P. \& TABER, H. W. (1989). Isolation and sequence of ctaA, a gene required for cytochrome $a a_{3}$ biosynthesis and sporulation in Bacillus subtilis. Journal of Bacteriology 171, 4967-4978.

Paulus, H. \& Gray, E. (1967). Multivalent feedback inhibition of aspartokinase in Bacillus polymyxa. I. Kinetic studies. Journal of Biological Chemistry 242, 4980-4986.

Petricex, M., Rutberg, L. \& Hederstedt, L. (1989). The structural gene for aspartokinase II in Bacillus subtilis is closely linked to the $s d h$ operon. FEMS Microbiology Letters 61, 85-87.

PIGGot, P. J. (1989). Revised genetic map of Bacillus subtilis. In Regulation of Procaryotic Development, pp. 1-41. Edited by I. Smith, R. A. Slepecky \& P. Setlow. Washington, DC.: American Society for Microbiology.

Piggot, P. J. \& НосH, J. A. (1985). Revised genetic linkage map of Bacillus subtilis. Microbiological Reviews 49, 158-179.

Pooley, H. M., Abellan, F.-X. \& Karamata, D. (1991). A conditional-lethal mutant of Bacillus subtilis 168 with a thermosensitive glycerol-3-phosphate cytidylyltransferase, an enzyme specific for the synthesis of the major wall teichoic acid. Journal of General Microbiology 137, 921-928.

Rosner, A. \& Paulus, H. (1971). Regulation of aspartokinase in
Bacillus subtilis. The separation and properties of the two isofunctional enzymes. Journal of Biological Chemistry 246, 2965-2971.

Ruhland, L. E., Work, E., Denman, R. F. \& Hoare, D. S. (1955). The behavior of the isomers of $\alpha, \varepsilon$-diaminopimelic acid on paper chromatograms. Journal of the American Chemical Society 77, 48444846.

SARGENT, M. G. (1973). Synchronous cultures of Bacillus subtilis obtained by filtration with glass fiber filters. Journal of Bacteriology 116, 736-740.

SChaeffer, P., Millet, J. \& Aubert, J. P. (1965). Catabolic repression of bacterial sporulation. Proceedings of the National Academy of Sciences of the United States of America 54, 704-711.

Shevtchenko, T. N., Okunev, O. V., Alexsieva, Z. M. \& Malyuta, S. S. (1984). Expression of genes for biosynthesis of lysine from Bacillus subtilis in cells of Escherichia coli. Citologia $i$ Genetika 1, $58-60$.

Shevtchenko, T. N., Timashova, E. O., Aleksieva, Z. M., Rodnin, N. V. \& MALYUTA, S. S. (1988). Bacillus subtilis mutants auxotrophic for lysine. Molekularnaya Genetika, Mikrobiologiya i Virusologiya 6 , 33-37.

SundHARAdAs, G. \& Gilvarg, C. (1967). Biosynthesis of $\alpha, \varepsilon-$ diaminopimelic acid in Bacillus megaterium. Journal of Biological Chemistry 242, 3983-3984.

Szabo, I., Penyige, A., Barabas, G., Szabo, G. \& Dinya, Z. (1989). Production of a streptomycine-Park nucleotide complex by Streptomyces griseus. Antimicrobial Agents and Chemotherapy 33, 58-62.

WARD, J. B. (1974). The synthesis of peptidoglycan in an autolysindeficient mutant of Bacillus licheniformis NCTC 6346 and the effect of $\beta$-lactam antibiotics bacitracin and vancomycin. Biochemical Journal 141, 227-241.

WARD, J. B. (1975). Peptidoglycan synthesis in L-phase variants of Bacillus licheniformis and Bacillus subtilis. Journal of Bacteriology 124, 668-678.

WORK, E. (1971). Cell walls. Methods in Microbiology 5A, 361-418.

ZEIGLER, D. R. (1990). Bacillus subtilis 168. In Genetic Maps, pp. 2.282.53. Edited by S. J. O'Brien. Cold Spring Harbor, NY: Cold Spring Harbor Laboratory.

Zhang, J. J. \& Paulus, H. (1990). Desensitization of Bacillus subtilis aspartokinase I to allosteric inhibition by meso-diaminopimelate allows aspartokinase I to function in amino acid biosynthesis during exponential growth. Journal of Bacteriology 172, 4690-4693.

Zhang J. J., Hu, F.-M., Chen, N.-Y. \& Paulus, H. (1990). Comparison of the three aspartokinase isozymes in Bacillus subtilis Marburg and 168. Journal of Bacteriology 172, 701-708. 